\title{
MEMBERSIHKAN SEPANJANG JALAN \\ DESA BONTOCINI
}

\author{
NURMEILANI \\ 9173770410300 \\ nurmeilaniiiii@gmail.com
}

1. Bentuk kegiatan

- Membersihkan pekarangan dan pinggiran jalan Desa Bontocini

2. Lokasi

- Desa Bontocini

3. Hari/tanggal dan waktu

- Senin 21 September 2020. Pukul 07:00 - 11:40

4. Peserta yang dilibatkan

- Mahasiswa KKLP YAPTI JENEPONTO

- Karang Taruna Desa Bontocini

- Masyarakat Desa Bontocini

- Kader PKK Bontocini

5. Alasan diadakan

Alasan diadakan kegiatan ini adalah karena terlalu banyak sampah yang berserakan di pinggir jalan Desa Bontocini sehingga tidak enak dipandang mata serta dapat menurunkan citra desa Bontocini di mata orang yang berlalu lalang.

6. Tujuan dan Manfaat

- Tujuannya adalah untuk membersihkan sampah - sampah yang berserakan di pinggiran jalan.

- Manfaatnya

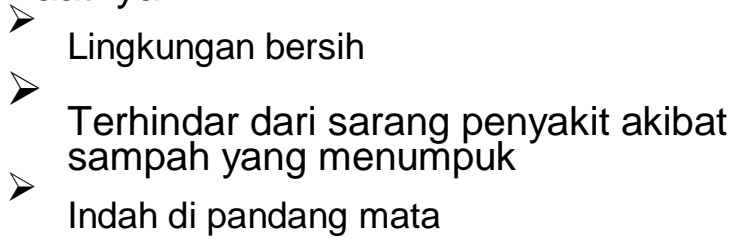

7. Deskripsi kegiatan 
Karang Taruna Desa Bontocini bekerja sama dengan mahasiswa KKLP Yapti Jeneponto dan masyarakat memulai kegiatan pukul 07:30 pagi yang kegiatannya berlangsung selama kurang lebih 5 jam. Kami membersihkan 4 Dusun yang ada di Desa Bontocini. Kami menyapu, membuang serta membakar sampah yang ada. Setelah kegiatan selesai kami kembali ke rumah Kepala Desa sebagai titik kumpul. 